\title{
Servant Leadership Model of Principal in Junior High Schools
}

\author{
Novi Irwan, Ganefri, Sufyarma Marsidin
}

\begin{abstract}
Servant leadership has been widely applied in various fields, both in educational organizations or companies and reveals that servant leadership is a leadership style that is relevant and suitable for the development of a leadership style in the 21st century where a principal leader must be able to serve the needs of teachers, education staff, and students in accordance with the demands of the development of science and technology which are very dynamic. This research aims to develop a valid, practical, and effective servant leadership model of school principals in Junior High Schools. This research is an $R \& D$ research by using the ADDIE model, namely analyze, design, development, implementation, and evaluation that is carried out in junior high schools in Agam Regency. Data collection techniques used instrument sheets, questionnaires, and documentation. Data were analyzed by using qualitative and quantitative analysis. The servant leadership model validation is determined based on expert responses. The practicality of the servant leadership model is determined based on the response of experts and school principals to the practicality of this model. The effectiveness of the servant leadership model is determined by the results of the expanded trial by the principal in Agam regency. The results of this research, it is obtained a principal servant leadership by producing products in the form of model books and school principal manuals that are valid, practical, and effective to use. The principal to improve leadership qualities namely can use the findings in this research, models of servant leadership are humanists, touches the heart in unity work logic, and actions that led to the creation of the atmosphere of the work.
\end{abstract}

Keywords: Model, Servant Leadership, Principal

\section{INTRODUCTION}

$\mathrm{S}_{\text {chool is an organizational institution that carries out a }}$ formal education process based on the type and level of the educational unit. The government's efforts in advancing education in Indonesia continues to be done on an ongoing basis. One is the reform of the main duties of the principal as the school leader [8]. "Principal is a leadership position that must be occupied through high consideration. The principal is a functional staff educator given the task to lead a madrasah in which organizes learning activity and promotes interaction between educators who provide lessons and learners who receive instruction" [1]. The principal duties of the school principal according to Permendikbud Number 6 of 2018 consist of three parts, namely; as managerial executor, as entrepreneurial development, and as an implementer of supervision for teachers and education personnel.

Revised Manuscript Received on November 30, 2020.

* Correspondence Author

Novi Irwan*, Doctoral Program of Education Science, Universitas Negeri Padang, Indonesia;

Ganefri, Universitas Negeri Padang Indonesia

Sufyarma Marsidin, Universitas Negeri Padang Indonesia

(C) The Authors. Published by Blue Eyes Intelligence Engineering and Sciences Publication (BEIESP). This is an open access article under the CC BY-NC-ND license (http://creativecommons.org/licenses/by-nc-nd/4.0/)
The Principal Duties of the Principal based on Article 15 of the Minister of Education and Culture Number 6 of 2018 concerning the Assignment of Teachers as School Principals are as follows: 1) The workload of the Principal is fully to carry out managerial main tasks, entrepreneurial development, and supervision of teachers and education personnel. Principal competencies required based on Permendiknas RI No.13 of 2007 include personal, managerial, supervision, entrepreneurship, and social competence. Principal managerial competence is a set of technical skills in performing duties as manager of the madrasah to utilize all resources available to achieve the objectives effectively and efficiently [11]. Leaders capture their past, present, and future pressures, challenges, and concerns, and aspirations with which they are daily faced and which reflect the multi-faceted demands of the role [10]. Leadership basically has the main essence of nature, ability, process, and concept that a person has [2]. To realize the main tasks of the principal is required a servant leader. Servant leadership characteristics help define personal responsibility for issues of social justice, human growth and potential, and human relationships, all of them which are essential for the helping professional [4]. Principals who just mastered the science of managerial, entrepreneurial, and supervision, but do not have a soul would serve the school will go on as usual and there will be changes. Servant leadership is a leadership style and motivates that Inspires others to Achieve the planned aims supportive through action by the leader [7]. The concept of servant leadership is providing excellent service to all school members, in other words, teachers who are appointed as school principals do not only serve as leaders who master managerial knowledge, entrepreneurship, and supervision but school principals who master managerial, entrepreneurial, and supervisory knowledge who are ready to provide servants to teachers, education staff, students, parents, the community and all stakeholders related to education [6]. The principal who serves is the principal who understands correctly what he should be placed as a leader in the school, whether just leading without reforming or a leader who wants to serve for the will of the school [9]. When the principal is aware and understands why he is a leader, then he will carry out the main task according to his conscience, namely how he must serve all stakeholders involved in education with excellent service and be ready to serve whatever the school community needs to achieve educational goals [14]. Based on observations of researchers at several schools in the district of Agam specifically junior high school, the principal who served following the concept of servant leadership is still much to what was expected.

Published By:

Blue Eyes Intelligence Engineering \& Sciences Publication

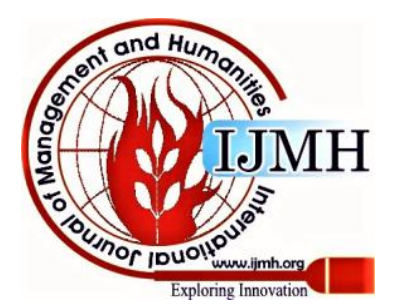


The principal who is given the task of being a leader in the school puts forward his position of power [5] compared to his main duties, namely how the principal serves school members in carrying out managerial duties, carrying out entrepreneurial duties and carrying out supervision teachers, meaning that principals are still bound by the old concept of the leader is someone who holds the power that must be respected, and served. If this concept is in each selfprincipals, then what is expected in the concept of servant leadership opposites. That teacher should be appointed head of the school should really be embedded inside her soul to serve. But on the contrary, if the principal does not have a soul to serve, then what is expected from No. 6 in 2018 Permendikbud stay to be a rule that must be implemented and not for the betterment of the school. The major advantage of this open Servant leadership style is that there is no permanent leadership position and this will give rise to several leaders who will rise to the top, keeping the interests of those served, in mind [3]. To optimize the role and duties of the principal required a transformation of an effective leadership style in encouraging optimal educational progress, especially in improving teacher performance under current standards and requirements. This is under the results of research [13] which explain that the serving leadership implemented by schools is based on value people, develop people, build community, display authenticity, provide leadership, dan share leadership. Based on several studies that have been previously disclosed servant leadership has been widely applied in various fields be it in education or enterprise organization and reveal that servant leadership is a leadership style that is relevant and suitable to the development of 21st-century leadership style in which a school principal leader must be able to serve needs- needs of teachers, educators, and learners under the demands of the development of science and technology is very dynamic.

\section{METHODOLOGIES}

This research is R\&D by using the ADDIE model, namely Analyze, design, development, implementation, and evaluation. The research was conducted in secondary schools in Agam District. Data collection techniques using sheet instruments, questionnaires, and documentation. Data were analyzed using qualitative analysis and quantitative analysis. Validation of the servant leadership model of leadership is determined based on the response of experts. Practicalities of the servant leadership model of leadership are determined based on the response experts and principals about the practicality of this model. The effectiveness of the leadership model of servant leadership is determined from the test results that were expanded by the principal in Agam District.

\section{RESULTS ANALISYS}

\section{a. Analyze Stage.}

Based on the questionnaire, obtained data on the implementation process needs analysis about servant leadership, for more details can be seen from the following figure:
Figure 1. Distribution Frequence of Needs Analysis

\begin{tabular}{|c|c|c|c|}
\hline No & Need Analysis & Frequence & Percentage \\
\hline 1 & Very needed & 9 & 15.00 \\
\hline 2 & Needed & 21 & 35.00 \\
\hline 3 & Simply Needed & 16 & 26.66 \\
\hline 4 & Less Needed & 10 & 16.67 \\
\hline 5 & Not needed & 4 & 6.67 \\
\hline \multicolumn{2}{|r|}{ Total } & 60 & 100.00 \\
\hline
\end{tabular}

Based on the fact that the case above, it is necessary to develop the design of "servant leadership principals". After a needs analysis is obtained then proceed with the design of the leadership model.

\section{b. Design Stage.}

In the design phase of model development, activities will make the design (blueprint) model based on the data obtained from analytical work. At this stage the researchers designed two (2) pieces of product development model consisting of; 1) book-based leadership model of servant leadership principals are valid, practical, and effective and 2) Guidebook servant leadership training leadership.

\section{c. Development Stage.}

Before describing the results of validation of the model book, first, formulate Aiken's V formula to calculate the content-validity coefficient based on the results of the assessment of an expert panel of 5 people on the item in terms of the extent to which these items represent the measured construct. It also conducted a test and test reliability ICC. Intra-class correlation coefficients (intraclass correlation coefficient) was used to assess the reliability between two or more experts. The results of data processing Aiken V, Reliability, and ICC of validation instrument models books can be seen in the following figure:

Figure 2. Aiken V, Reliability, and ICC of Instruments Model Validation

\begin{tabular}{|c|c|c|c|c|c|}
\hline $\begin{array}{c}\text { Typ } \\
\text { e of } \\
\text { Data }\end{array}$ & $\begin{array}{l}\text { Collectio } \\
\text { n } \\
\text { technique } \\
\text { s }\end{array}$ & $\begin{array}{c}\text { Research } \\
\text { Instrumen } \\
\text { ts }\end{array}$ & $\begin{array}{c}\text { Aiken } \\
\text { V }\end{array}$ & $\begin{array}{c}\text { Reliabi } \\
\text { lity }\end{array}$ & ICC \\
\hline \multirow{4}{*}{$\begin{array}{l}\text { Qua } \\
\text { ntitat } \\
\text { ive }\end{array}$} & \multirow{4}{*}{$\begin{array}{l}\text { Validatio } \\
\text { n } \\
\text { Questionn } \\
\text { aire }\end{array}$} & Desaign & $\begin{array}{c}0.888 \\
\text { (Valid } \\
\text { ) }\end{array}$ & $\begin{array}{l}0,857 \\
\text { (Very } \\
\text { high) }\end{array}$ & $\begin{array}{c}0,857 \\
\text { (excellen } \\
\text { t) }\end{array}$ \\
\hline & & Content & $\begin{array}{c}0.869 \\
\text { (Valid } \\
\text { ) }\end{array}$ & $\begin{array}{l}0,885 \\
\text { (Very } \\
\text { high) }\end{array}$ & $\begin{array}{c}0,885 \\
\text { (excellen } \\
\text { t) }\end{array}$ \\
\hline & & Graphics & $\begin{array}{c}0.881 \\
\text { (Valid } \\
\text { ) }\end{array}$ & $\begin{array}{l}0,831 \\
\text { (Very } \\
\text { high) }\end{array}$ & $\begin{array}{c}0,831 \\
\text { (excellen } \\
\text { t) }\end{array}$ \\
\hline & & Language & $\begin{array}{c}0.875 \\
\text { (Valid } \\
\text { ) }\end{array}$ & $\begin{array}{l}0,902 \\
\text { (Very } \\
\text { high) }\end{array}$ & $\begin{array}{c}0,902 \\
\text { (excellen } \\
\text { t) }\end{array}$ \\
\hline
\end{tabular}

According to the figure 2 above, it can be concluded from the results of the validation instrument by experts of the overall the model of servant leadership in language point an average of Aiken-V 0.888 or are in the category valid, reliability 0.857 or are in the category of very high, and the ICC 0.857 or are in the excellent category.

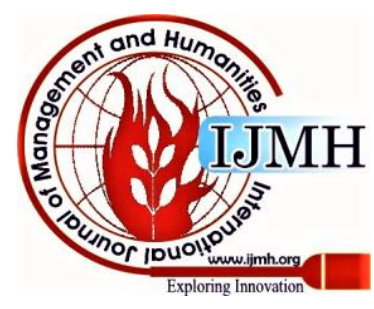


In terms of content get an average of Aiken-V 0.869 or are in a valid category, reliability 0,885 or be in the very high category, and 0,885 ICC or are in the excellent category. In terms of graphics get an average of Aiken-V .881 or are in a valid category, reliability 0.831 or are in the category of very high, and the ICC 0.831 or be in either category yet. In terms of language earn an average of AikenV 0.875 or are in a valid category, reliability 0.902 , or are in the category of very high, and ICC is .902 or better in all categories.

Expert validation results for this instrument show that in terms of content, graphics, language, and design of the book learning model of servant leadership is leadership in the category valid for use.

Having seen the Aiken V test, reliability, and ICC of instrument validation of the model book, the following will be presented the results of the validation by experts and practitioners to book the following models;

Figure 3. Results of Model Validation Servant Leadership

Conclusion Results of Model Validation Servant Leadership

\begin{tabular}{|c|l|c|c|}
\hline \multicolumn{4}{|c|}{ Leadership } \\
\hline No & Aspects Assessed & Average & Category \\
\hline 1 & Content & 4.18 & Good \\
\hline 2 & Graphic & 4.19 & Good \\
\hline 3 & Language & 4.40 & Excellent \\
\hline 4 & Design & 4.28 & Excellent \\
\hline \multicolumn{2}{|c|}{ Average } & 4.26 & Excellent \\
\hline
\end{tabular}

According to the figure 3 above, it can be concluded from the results of the validation by experts of the overall book of servant leadership model of leadership in terms of getting an average content of 4.18 or be in either category, in terms of graphic get an average of 4.19 or are in the category good, in terms of the language to get an average of 4.40 or are in the excellent category, and in terms of getting an average content of 4.28 or are in the very good category. Overall, the results of expert validation on this book show that in terms of content, graphics, language, and the design of the servant leadership learning model book, it gets an average of 4.26 or is in the very good category. All validator's consensus view is that this book deserves to be used with minor revisions, meaning that all aspects were judged on criteria that can be accepted, so it does not require major revision and revalidation.

The results validate the leadership guide books servant leadership principals according to experts (expert) that are in the very good category with an overall average of 4:30. The assessment was performed by 5 experts with the number of grains of the questionnaire as much as 25 . It can be inferred that the leadership of servant leadership guide books are in a very good category. All validator's consensus view is that this book deserves to be used with minor revisions, meaning that all aspects as being at acceptable criteria so that it does not require major revision and revalidation. As suggested by the validators, experts, and FGD participants, revisions were made to the model book and manual. The revision results are briefly shown in the table below. The revised at this stage produce a prototype II valid and can be continued on a limited trial basis. This was followed by limited testing done to see if the model conforms with the purpose expected before entering into an expanded test. Before the model is implemented beforehand researchers provide insights into the principal's instructions on the implementation of the model in the learning process in the classroom. Based on the results of trials that have been done in junior high school in the Agam result is that school leadership with the leadership model of servant leadership principals in improving the performance of teachers in junior high school can be carried out with an average of 4.07 or in the good category. Following the results of the trials conducted further expanded the leadership model of servant leadership to the school principal.

\section{d. Implementation Stage}

\section{Practicality}

The practical data of model book were obtained from a questionnaire given to 5 validators who are experts in their fields. For more details, can be seen in the following figure.

Figure 4. The practical data of model book Servant Leadership.

\begin{tabular}{|c|c|c|l|}
\hline Grain & Average & TCR & Conclusion \\
\hline 1 & 4.50 & 90.00 & Very Practical \\
\hline 2 & 4.76 & 95.29 & Very Practical \\
\hline 3 & 4.71 & 94.12 & Very Practical \\
\hline 4 & 4.76 & 95.29 & Very Practical \\
\hline 5 & 4.59 & 91.76 & Very Practical \\
\hline 6 & 4.53 & 90.59 & Very Practical \\
\hline 7 & 4.69 & 93.75 & Very Practical \\
\hline 8 & 4.82 & 96.47 & Very Practical \\
\hline \multicolumn{2}{|c|}{ Overall average } & \multicolumn{3}{|c|}{ 93.41 } \\
\hline \multicolumn{2}{|c|}{ TCR } & \multicolumn{3}{c|}{ Very Practical } \\
\hline \multicolumn{2}{|c|}{ Conclusion } & \multicolumn{3}{c|}{} \\
\hline
\end{tabular}

Can be explained that the book practicalities of servant leadership model leadership principals view the practicalities of each grain of the aspects of the assessment. The items rated as many as 8 grains. From all these points, it is stated that it is very practical. This means that the model book developed is very practical or good to use. The practicalities assessment was carried out by 21 respondents consisting of 5 people validator and 16 principals. It can be concluded that the overall indicators of aspects of the assessment above, the obtained average is 4.67 , or are in the category of very practical, then the practicalities of the leadership model of servant leadership books principals expressed very practical and fit for use.

Manual data on practicality was obtained from a questionnaire given to 5 validators who are experts in their fields and 16 head masters. For more details, can be seen in the following figure.

Figure 5. Manual data on practicality Servant Leadership model Head Master.

\begin{tabular}{|c|c|c|c|}
\hline Grain & Averge & TCR & Conclusion \\
\hline 1 & 4.53 & 90.59 & Very Practical \\
\hline 2 & 4.76 & 95.29 & Very Practical \\
\hline 3 & 4.59 & 91.76 & Very Practical \\
\hline 4 & 4.76 & 95.29 & Very Practical \\
\hline 5 & 4.88 & 97.65 & Very Practical \\
\hline 6 & 4.71 & 94.12 & Very Practical \\
\hline
\end{tabular}




\begin{tabular}{|c|c|c|c|}
\hline 7 & 4.12 & 82.35 & Practical \\
\hline 8 & 4.47 & 89.41 & Very Practical \\
\hline 9 & 4.53 & 90.59 & Very Practical \\
\hline 10 & 3.76 & 75 & Practical \\
\hline 11 & 4.47 & 89.41 & Very Practical \\
\hline 12 & 4.71 & 94.12 & Very Practical \\
\hline 13 & 4.65 & 92.94 & Very Practical \\
\hline 14 & 4.18 & 83.53 & Practical \\
\hline 15 & 4.47 & 89.41 & Very Practical \\
\hline 16 & 4.47 & 89.41 & Very Practical \\
\hline 17 & 4.18 & 83.53 & Practical \\
\hline 18 & 4.00 & 80.00 & Practical \\
\hline Overall average & \multicolumn{3}{|c|}{4.46} \\
\hline \multicolumn{2}{|c|}{ TCR } & \multicolumn{3}{|c|}{ Very Practical } \\
\hline \multicolumn{2}{|c|}{ Conclusion } &
\end{tabular}

Based on the results obtained, it can be explained that the practicalities of guide books servant leadership principals leadership in the overall view of the practicalities of the 18 items in the category ratings are very practical. This was done by 5 validators and 16 school principals. Of the 18 grains of assessments performed 13 items that are in the category of very practical and 5 grains are in the practical category. This means that the servant leadership work guidebook for principals is practical and feasible to use. It can be concluded that the overall indicator of the importance of the evaluation aspects above average is 4:46 or very practical. Then the practicalities of leadership guide books servant leadership principals expressed very practical and fit for use

\section{Effectiveness}

Based on research conducted on a sample class, the questionnaire obtained data about the effectiveness of the model of servant leadership principals. The data obtained from the final phase of the research activities. The data will be described consists of two groups: Experimental Data principals who use the model of servant leadership and control group data obtained from the data principals without using a model of servant leadership. Schools that are taken in this study is the first high school, which is located in the Agam district consists of 20 schools and 20 control schools experiment. The normality test was carried out on variables manually and using the SPSS 16.0 for Windows program using the Kolmogorov-Smirnov test (K-s test) with the criteria if the Kolmogorov-Smirnov Z value was Asymp. Sig. (2-tailed) $>0.05$, then the data came from a normally distributed population. Based on calculations of data normality test consisting of 20 respondents regarding the experimental data and the control data and the calculation results obtained from the tests of normality were seen Asymp value. Sig (2-tailed) experiment $0.667>0.05$ and 0.975 control class $>0.05$. Asymp value price. Sig (2-tailed) which is greater than the price of $\alpha=0.05$. Thus, it can be concluded that Ho is rejected and all groups of data in this study were drawn from the normally distributed population so that it can be used and continued to research hypothesis testing. Further tests were conducted to determine the homogeneity of variance of the data similarity experimental class and the control class data. The homogeneity test was carried out on the variables using SPSS 16.0 for Windows test Levene statistical test (test L-s). Based on calculations Levene homogeneity test statistic test (test L-s) over the study variables, showed that the value of sig $0.749>0.05$. Price value Levene statistical test (test L-s) which is greater than the price of $\alpha=0.05$. Thus, we can conclude that all groups of data in this study were taken from a homogenous population, so it can be used and continue to test the research hypothesis.

After the test for normality and homogeneity test followed by a test t-test, to determine whether there is a significant difference to the value of the two groups. Here will be described the processing of data by t-test:

Figure 6. Calculation Result Data with t-test Experiment Class Value and Control Class

\begin{tabular}{|c|c|c|c|c|c|c|c|c|}
\hline & & \multicolumn{7}{|c|}{ t-test for Equality of Means } \\
\hline & & \multirow[b]{2}{*}{$\mathrm{t}$} & \multirow[b]{2}{*}{ Df } & \multirow{2}{*}{$\begin{array}{c}\text { Sig. } \\
(2- \\
\text { tailed })\end{array}$} & \multirow{2}{*}{$\mid \begin{array}{c}\text { Mean } \\
\text { Differen } \\
\text { ce }\end{array}$} & \multirow{2}{*}{$\begin{array}{c}\text { Std. } \\
\text { Error } \\
\text { Differen } \\
\text { ce }\end{array}$} & \multicolumn{2}{|c|}{$\begin{array}{l}95 \% \text { Confidence } \\
\text { Interval of the } \\
\text { Difference }\end{array}$} \\
\hline & & & & & & & Lower & Upper \\
\hline \multirow[t]{2}{*}{ Data } & $\begin{array}{l}\text { Equal } \\
\text { variances } \\
\text { assumed }\end{array}$ & 3.938 & 38 & .000 & 30.900 & 7.848 & 15.014 & 46.786 \\
\hline & $\begin{array}{l}\text { Equal } \\
\text { variances not } \\
\text { assumed }\end{array}$ & 3.938 & 37.282 & .000 & 30.900 & 7.848 & 15.003 & 46.797 \\
\hline
\end{tabular}

Sources : Processed by SPSS 16.00 Windows [12]

Seen in table $t$ for df 38 at a significant level of 0.05 is 1.68. Based on the results of the $t$-test on the result that $t>t$ table is 3,938 $>1.68$ and a significance level of $<0.05$ is 0.000 , it can be concluded that the hypothesis $\mathrm{H} 1 \mathrm{HO}$ is accepted or rejected. It can be concluded that there is a difference between the experimental class that uses a model of servant leadership principals leadership compared with the control class without using a model of servant leadership principals leadership.

\section{e. Evaluation Stage}

The evaluation stage is the final stage of product development. The evaluation phase is carried out to determine the quantity and quality results of the product being developed. Evaluation is carried out to determine the results of the validity, effectiveness, and practicality of product development. The results of the validity were obtained from the calculation of the validator's assessment sheet. The effectiveness result is obtained from the calculation of the teacher questionnaire on the servant leadership of the principal. Practicality results obtained from the average calculation of the response questionnaire from the validator and the principal. The existence of an effective and dynamic leader in the organizational structure is very strategic. Because with a high commitment from a leader to improve the quality of his subordinates, it is hoped that the quality of his subordinates will also increase. An effective and dynamic leader will be able to control, direct, and motivate his subordinates towards achieving employee work productivity, as expected by leaders in an organization. 


\section{CONCLUSION}

Based on the results of research and discussion that has been described in previous chapters, it can be concluded as follows: 1) The form of the development model of servant leadership (servant leadership) principals School seen from the duties of the principal as supervisory, managerial, and entrepreneurship by applying the characteristic of servant leadership displays authenticity, provide leadership, persuasive mapping visionary, wisdom, shared leadership, altruistic calling, emotional headling, and develop people, 2) leadership model of servant leadership principals already fit for use after rated valid, practical and effective by established criteria.

\section{ACKNOWLEDGMENT}

Thank you very much to the entire academic community, school principals, teachers / educators and education staff and a number of friends so that this article can be completed. Especially to the promoter, Prof. Ganefri, M.Pd., Ph.D. and Prof. Dr. Sufyarma Marsidin, M.Pd.

\section{REFERENCES}

1. Asmendri, A., Marsidin, S., Rusdinal, R., \& Mukhaiyar, M. (2018). An analysis of managerial competence of the madrasah principals in Islamic senior high school Tanah Datar. Al-Ta Lim Journal, 25(1) doi:http://dx.doi.org/10.15548/jt.v25i1.350

2. Azni Fithri, Mukhaiyar \& Rusdinal. Pengaruh Kepemimpinan Pengelola, Iklim Komunikasi Dan Motivasi Kerja Terhadap Kinerja Tutor Pada Pkbm Karang Putih Kelurahan Batu Gadang Kecamatan Lubuk Kilangan Kota Padang. Liingua Diidakttiika Volume 5 No 1, Desember 2011.

3. Doraiswamy, Iyer Ramajanaki. 2013. Servant Leadership in Teaching. International Journal of Human Resource Studies ISSN 2162-3058 2013, Vol. 3, No. 1.

4. Fields, Joyce, et all. 2015. Servant Leadership: Teaching the Helping Professional. Journal of Leadership Education. DOI:10.12806/V14/I4/R2.

5. Khalifa, M. A., Khalil, D., Marsh, T. E. J., \& Halloran, C. (2019). Toward an Indigenous, Decolonizing School Leadership: A Literature Review. Educational Administration Quarterly, 55(4), 571-614. https://doi.org/10.1177/0013161X18809348.

6. Kuanprasert, K. (2019). The Relationship between Servant Leadership of School Administrator and Job Motivation of Teachers under Saint Maria Academy. Asian Political Science Review, 3(2), 89-95.

7. Malingkas, Melky et all. 2018. The Effects of Servant Leader and Integrity of Principal Performance In Catholic Senior High Schools in North Sulawesi, Indonesia. Journal of International Education and Leadership Volume 8 Issue 1 Spring 2018 http://www.jielusa.org/ ISSN: 2161-7252.

8. Nuridin, N., Maerani, I. A., Soleh, M. M. A., \& Anwar, K. (2019). Meningkatkan kompetensi kepala sekolah swasta di Kota Semarang berdasarkan Permendikbud Nomor 6 Tahun 2018. Indonesian Journal of Community Services, 1(2), 165-174.

9. Palta, A. (2019). Examination of Teachers' Perceptions about Servant Leadership and Organizational Commitment. International Education Studies, 12(4), 36. https://doi.org/10.5539/ies.v12n4p36

10. Sabanci Ozer, H. (2012). The Role of Family Control on Financial Performance of Family Business in Gebze. International Review of Management and Marketing, 2(2), 75-82

11. Sabandi, A., Anisah, A., \& Rusdinal, R. (2018). Training Needs Analysis: Study on Development of School Administration's Competence. Journal Of Educational Review and Research, 1(1), 1524.

12. SPSS Stdent Version 16.0: For Microsoft Windows XP or Vista. 2008. Inc. Spss, Pearson Precentice Hall.

13. Sri Wening Rahayu \& Conny Benyamin. Penerapan Kepemimpinan Melayani (Servant Leadership) Bidang Penguatan Karakter Guru dan Siswa. Jurnal Dinamika Manajemen Pendidikan (JDMP) Volume 5, Nomor 1, 2020., hlm. 29-35 ISSN: E-ISSN : 2540-7880 DOI 10.26740/jdmp.v5n1.p29-35.

14. Wu, J., Liden, R. C., Liao, C., \& Wayne, S. J. (2020). Does Manager Servant Leadership Lead to Follower Serving Behaviors? It
Depends on Follower Self-Interest. Journal of Applied Psychology. https://doi.org/10.1037/apl0000500

\section{AUTHOR PROFILE}

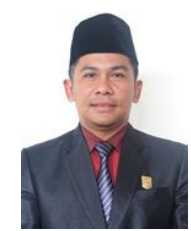

Novi Irwan, was born in Koto Nan Gadang on 20-09 1976. Worked as Chairman of the DPRD Agam, Chairman of the Trustees of YIKC / Agam and Payakumbuh. Education history of S1 Mechanical Engineering, State University of Jakarta (2001), Masters in HR Management at STIE Wiidyajayakarta (2006). Head of the Insan Karima Cendikia Foundation, Managers of the Al Azhar Bukittinggi Islamic School, Agam and Payakumbuh. Pengdasmen PD Muhammadiyah of Agam Regency, Supervisor of Minang Jaya Student Center / KMM Agam, Chairperson of the Agam Community Coordination body / Bakor Agam, Deputy Chairperson of BPKRMI West Sumatra, General Chairperson of KSJ, General Chairperson of KMM Jaya Central Management, Muhammadiyah Youth Center Management Activists, Management Gebu Minang Youth, East Jakarta PMR Technical Guidance, General Chairperson of KMM UNJ. Has been a lecturer in mechanical engineering at STT 10 November Jakarta. Lecturer in Management at STIE Tunas Nusantara-Jakarta

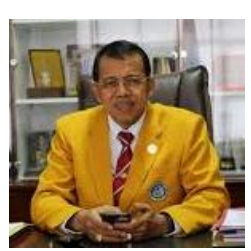

Ganefri, is a professor in the Faculty of Engineering Universitas Negeri Padang and a lecturer, lecturer, and Indonesian technical academic. He is the Chancellor of Padang State University for the 2016-2020 period and was reelected for the 2020-2024 period. He is also listed as a member of the Bung Hatta University Board of Trustees. Ganefri was born on December 17, 1963 (age 57 years), in Payakumbuh, West Sumatra. Previously Prof. Ganefri serves as Chairman of Kopertis Region X and Dean of the Faculty of Engineering (FT) Padang State University. Graduated with a Bachelor of Electrical Education from IKIP Padang (1988), he continued his Postgraduate Study of Technical and Vocational Education at IKIP Yogyakarta (1996) and earned a Doctorate in Vocational Technical Education at UKM Malaysia (2011). Some of his scientific articles include family business succession of SMEs and post-transition business performance. Effectiveness of interactive instructional media on electrical circuits.

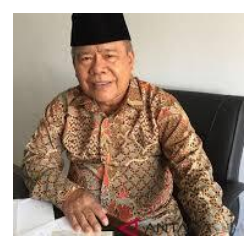

Sufyarma Marsidin, (born in IV Angkek, Agam, West Sumatra, February 9, 1954; age 66 years) is a professor of Educational Management at the Faculty of Education (FIP), P. [1] He served as Chairman IV of the Central Board of the Indonesian Bachelor of Education Association for the 2014-2019 term. [2] He was a member of the West Sumatra Provincial DPRD for two periods, 1990-1992 and 1992-1997. In 2007-2010, he served as Head of the Agam District Education Office. Some of his scientific articles are the selective capita education management, the dominant factors influencing career direction planning (studies on SMA Negeri Kota Pariaman.) Developing the active learning model to improve the effectiveness study group on entrepreneurship in higher education (a case at the art Institute of Indonesia Padangpanjang)
Published By:

Blue Eyes Intelligence Engineering \& Sciences Publication

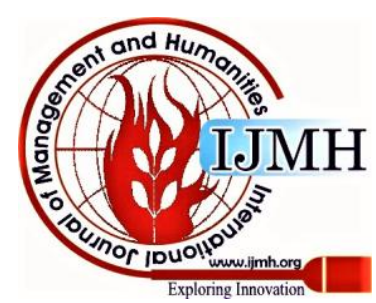

